\title{
THE DEVELOPMENT OF EGLISH INSTRUCTIONAL DESIGN SOCIAL LEARNING NETWORK (SLN)-BASED USING AUCTION (INTERESTED- BASED NEGOTIATION) STRATEGY
}

\author{
M. As'at, Punadji Setyosari, Saida Ulfa \\ Universitas Negeri Malang \\ Email: muhammad.asat@gmail.com
}

\begin{abstract}
The purpose of the reseach is to create an english instructional desain social learning network (SLN)-based platform Edmodo using Auction (interestedbased negotiation) strategy. It can be one of creative solutions to overcome a limited time in english learning process in a lesson plan package. The method of developing is used in this research is Lee \& Owen (2004). The 5 development steps are as follow : 1) analysis; 2) design; 3) development; 4) implementation; 5) evaluation. The product was evaluated by the experts which is the everage is 89,3\% and 24 students from Indonesian Air Force Abd Saleh Language School Malang is $89,8 \%$. In conclusion, the product is completly valid and could be implemented in learning proses.

Keywords : social learning network, edmodo, auction
\end{abstract}

\section{INDTRODUCING}

Preparing its members for the national weaponry system deployment and the world peacekeeping mission, Indonesian Air Force holds intensive English course (KIBI) which is cunducted every year in Language Schools all over Indonesia. One of the Language Schools is Abd Saleh Language School located in Abd Saleh Air Force Base, Malang. Within the course, KIBI focuses on the progress of the language skills; Reading, Listening, Speaking and Writing as well as the Structure/Grammar as the foundation to sustain the progress on those skills.

Based on the observation result in Abd Saleh Language School, some students are able to display their knowledge in English especially in diction, sentence pattern, and simple pattern of spoken language to communicate, yet the matter arouses when they have to develop the complexity of the tenses even more when it is the Perfect Tense.
One of the factors becoming obstacles for the students in Abd Saleh Language School is related to education method. The method used is basically face to face and the role of the instructors becomes more central and the students become the object of the education rather than the subject of the education. This matter becomes more tense when the allocated time for the Lesson Perfect Tense is somehow is not ample for the students to understand the cope. Based on the curriculum for KIBI elementary class Indonesian Air Force, the allocated time for lesson hours for grammar is generally 90 lesson hour from 703 lesson hours (@ 45 minutes) (Kepkasau.2013). The 90 lesson hours are divided 11 lessons so that tenses discussion only 8 lesson hours. Then those 8 lesson hours are applied to discuss the 16 tenses. With the allocated time 0,5 lesson hours per tenses, it is even not enough to understand the lesson.

The strategy in giving the
lesson has imminent role in

Development of English .... -As'at- || 15 
education process rather than the lesson itself. Degeng (2013) states that there are three (3) components to give the perception of delivery strategy; (1) education media,(2) students' interaction to media, (3) the form of the lesson. The proper media for a lesson must be selected based on the analysis of students' characters and the environment where the lesson takes place.

E-learning design development requires the latest lesson approach concept, the challenges related to the previous concept on the running program so that redesign the pattern in delivering the lesson is highly required to set a chance for the instructors in giving assessment, feedback, and interaction between the instructors and the students ( Rugiero \& Boom, 2015). In some researches, the goals in a webbased lesson, (1) Gale dan Kariv (2003) in the research title Bayesian Learning in Social Network shows a good result in learning by using social network.

Huang,J.\&Yang\&Huang,Y.\&Hsio (2010) with the title Social Learning Network : Build Mobile Learning Network Based on Collaborative Service within the social network displays a significant result that students can interact and shade a better lesson.

Edmodo is a social learning network media platform in E-learning which is portrayed as Facebook for school and functions more than it is expected. Edmodo is an interesting application for instructor and students with the social element resemblance Facebook. In fact, there is a great value within this social networking-based education application.. Edmodo (designed for teachers) is an application which is safe to use for instructor and students. Cauley (2012) in Zein (2016) says that by using edmodo students can do collaborative learning with high intensity to communicate and well-interaction between either with instructors or the classmates.

The basic concept of how to use Edmodo in a lesson is virtual class where the students able to use Edmodo without any barriers. Edmodo can be used from mobile phone since its application can be downloaded at Play Store. The usage of Edmodo in English Class needs a lesson plan so that the lesson becomes more effective. Within lesson plans, we can explore the consideration aspect for any factors concern on how it is affect or effect by any planning action (Punaji.2001). An interesting and creative lesson strategy is needed to avoid monotonous lesson process and focus the progress so that instructors and students can study enthusiastically and get the deepest understanding from the lesson.

Auction Lesson Strategy (Interested-based negotiation) can become alternative solution in a lesson using Edmodo. This strategy is related to cooperative learning lesson which puts students as subject within the lesson. English Auction Learning Strategy is based on the specific proses on sharing the knowledge with negotiation (Burato andCristani,2009). In this strategy, students are demanded their role in negotiation against other groups of students especially their knowledge to analyze a problem and study the strategy to win the game.

The use of Auction Strategy in SLN-based English Learning will give another option which is more interesting and motivating students to be active in the learning process since 
there is a game element (gamafication) packed in a lesson. Lee and Hammer say (2011) gamification are elements from games e.g : world of warcraft designed for learning. According to Kapp (2012) " gamification is using games based mechanics, aesthetics and games thinking to engage people, mativate action, promote learning, a nd solve problems". Based on the facts above, gamification is a learning method based on rules, beauty, and thought in games to involve students so that it can motivate and develop the lesson and problem solving agent.

\section{RESEARCH METHOD}

This learning media research and development adapts the development model from Lee and Owens (2004) with the scheme Analysis, Design, Development, Implementation, and Evaluation.

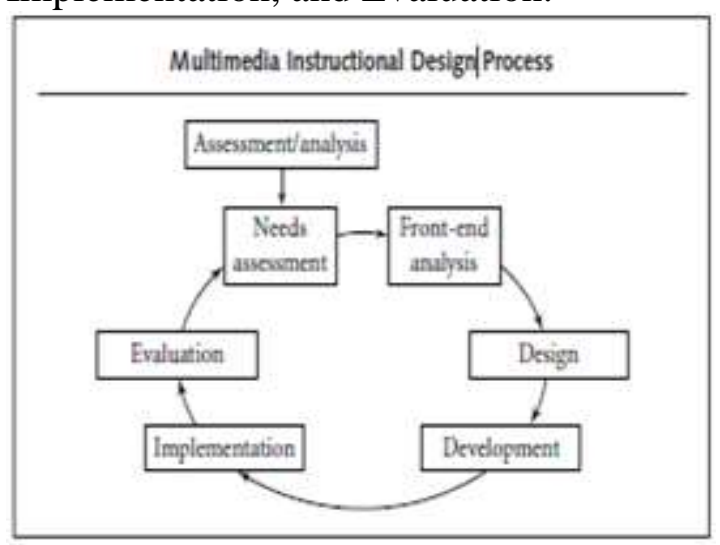

Picture Multimedia Development Scheme Lee \& Owens

\section{Analysis}

KIBI Students in Abd Saleh are mostly from Indonesian Air Force with different rank and corps. Students start the day bay holding morning roll call and then continue to classroom activity so that students can pay their role in the class and understand the deep comprehension on the lesson. KIBI students are acknowledge on how to use social network to their classmates or instructor to communicate or do the assignment. Students' character varies from one to another. Some students are ease to study and learn, some students may not.

Students may have different style in learning, too. They should be active, yet some students may still have hesitation to share ideas or opinion during the class. This may happen since students are lack of confidence since they are not English literate, students feel that the allocated time for studying in the class is limited, or even students are not ease with the different rank they have in the Air Force. Seniority in the Air Force may impact on their motivation to learn more. KIBI Students tend to like visual learning. They prefer to use their gadget (mobile phone/laptop) as a learning media. Students have already had the average skills in English but the skills vary from one to another. Students who are officers may have better understanding rather than the Non-Commissioned Officer.

\section{Design}

Finishing the need analysis and also pre and post analysis, the next step is to design the product. Lee and Owen (2004) Design stage is a stage where the multimedia is planned. Here, there several steps must be done as follows :Scheduling, working team planning, media specification assuring, frame work making, product control and evaluation. The schedule of research planning and the development of learning English design based on SLN with Auction strategy (interestedbased negotiation) is done on October 2016 until May 2017. The activity is started from the designing the research 
proposal until product testing in the field. Edmodo is the media used for this research and development using the auction. Lesson used in this research are : 1)Lesson1 : Present Perfect Tense; 2)Lesson 2 : Present Progressive Tense; 3)Lesson 3 : Past Perfect Tense; 4)Lesson 4 : Past Perfect Progressive Tense; 5)Lesson 5 : Future Perfect Tense; 6)Lesson 6 : Future Perfect Progressive Tense.

\section{Development and Implementation}

There is implemented result in the developmental stage of the media

\begin{tabular}{|l|l|l|}
\hline $\begin{array}{l}\text { Percentage } \\
(\%)\end{array}$ & Score & Remark \\
\hline $76-100$ & 4 & Valid \\
$51-75$ & 3 & Valid \\
$26-50$ & 2 & enough \\
$0-25$ & 1 & Less Valid \\
& & Invalid \\
\hline
\end{tabular}

from the units that has been developed. The implementation of the Learning media development is compiled the same as the running learning model. Generally, Social learning network is designed for learning activity which has its functions as supplementary activity done after class. It is expected that students can use it everytime and everywhere. Yet, the use of edmodo in the classroom using auction learning strategy must be set so that it can run effectively and efficiently and students may get involved and attracted to the program. The stages of Auction in virtual class using edmodo as follow : 1) Introducing the Topic; 2)Grouping; 3)Giving budget; 4)Auction; 5)Reward.

\section{Evaluation}

Scoring is aimed to demonstrate whether the media made achieve the goals or not. Validity used in the media is content validity and design validity. Content validity is related to the proper lesson used in the media which should in line with the goals want to achieve and the curriculum. Meanwhile design validity concerns on the ease of understanding the lesson through the media made. The instruments used for checking the validity is in the form of monkey survey. Data which are collected are then analyzed by using the percentage techniques in each item and the data is maintained thoroughly. The result of the development product is then tested. The testing designs in the development are : Instructional material expert, Instructional design expert, Instructional media expert, students/class is done by collecting 24 of Indonesia KIBI students as samples in Abd Saleh Language School. The follong table shows product validity criteria (Arikunto,2010):

\section{RESULT}

\section{Instructional Material Expert}

Based on the result of the experiment, Instructional material expert can be analysized that 15 aspects fullfil from 18 aspects required. It means $76 \%-100 \%$ and show the tendency of valid. The other 3 aspects are related to the proper aspect of video shown connected to the lesson given, the clarity of sentence form, and the easyness of how the context is understood shown by the proper 
diction. Based on those data, the percentage shown is $77 \%$. It means that it is valid trough the data interpretation since the value is $77 \%$ and the range for valid is $76 \%$ $100 \%$.

\section{Instructional Design Expert}

The Assesment of Instructional media Expert to the design of English lesson using edmodo with auction strategy to each indicator shows that the percentage of each of them range from $80 \%-100 \%$. It means that the achievement level of the lesson design belongs to valid qualifiaction so it does not need and revision.

\section{Instructional Media Expert}

The Assesment of Lesson Media Expert to the design of English lesson using edmodo with auction strategy to each indicator shows that the percentage of each of them range from $80 \%-100 \%$. All indicators get $100 \%$. Indicator that only recieve $80 \%$ is an indicator on "The appeal of the feature in edmodo chosen as facility in giving the quiz, grouping, action and evaluation in Auction Strategy. but this indicator only. It means beside that indicator have percentage of $100 \%$. It means that the level of achievement teacher handbook product belong to the qualification of valid and need no revision.

\section{Field/class Evaluation}

Class/big group testing scoring against the design of English lesson Edmodo platform-based with Auction strategy in each indicator shows that the percentage in each indicator range from $80 \%-100 \%$. It means that the achievement level of the lesson design belongs to valid qualifiaction so it does not need revision.

\section{The Recapitulation of Testing Data Percentage}

The recapitulation of the assesment result from all the testing subject in this development is aimed to acknowledge the average percentage acquired in the developed product which is the English lesson plan using auction strategy. The following are the result of the overall assesment.

The result of the data explanation and analysis on the lesson plan is shown as follow :

\begin{tabular}{|c|c|c|c|c|c|}
\hline $\begin{array}{l}\mathbf{N} \\
\mathbf{0} .\end{array}$ & Subject & $\begin{array}{l}\text { Ma } \\
\text { X. } \\
\text { Sco } \\
\text { re }\end{array}$ & $\begin{array}{l}\text { Asses } \\
\text { ment }\end{array}$ & $\begin{array}{c}\text { Percen } \\
\text { tage } \\
(\%)\end{array}$ & $\begin{array}{c}\text { Rem } \\
\text { ark }\end{array}$ \\
\hline 1. & $\begin{array}{c}\text { Instructi } \\
\text { onal } \\
\text { Material } \\
\text { Expert }\end{array}$ & 90 & 69 & 77 & Valid \\
\hline 2. & $\begin{array}{c}\text { Instructi } \\
\text { onal } \\
\text { Design } \\
\text { Expert }\end{array}$ & 90 & 84 & 93 & Valid \\
\hline 3. & $\begin{array}{c}\text { Instructi } \\
\text { onal } \\
\text { Media } \\
\text { Expert }\end{array}$ & 75 & 74 & 98,7 & Valid \\
\hline 6. & $\begin{array}{c}\text { Field/cla } \\
\text { ss } \\
\text { Evaluati } \\
\text { on }\end{array}$ & $\begin{array}{l}1.8 \\
00\end{array}$ & 1.535 & 85,3 & Valid \\
\hline
\end{tabular}

Data recapitulation is conducted just right after the data from the experts testing and students testing. From the above table, it is clearly seen that the assesment result for all the testing subject is 2.363 and the maximum score for all the testing subject is 2.730 . From the data then it is calculated for all aspect using the following pattern.

$$
\mathrm{P}=\frac{\text { Assesment }}{\text { Max. Score }} \times 100 \%
$$

Note :

$\mathrm{P}=$ Validity Percentage 
$100 \%=$ Konstanta

The calculation is written as follow:

$=\frac{1762}{2055} \times 100 \%$

$=85,74 \%$

Based on the data calculation, overall percentage shown is $\mathbf{8 5 , 7 4 \%}$. Based on data interpretation, the result belongs to percentage range $\mathbf{7 6 \%}$ 100\%. It means that Engslish lesson plan SLN-based using auction strategy belongs to the qualification of valid.

\section{STUDY}

The development of english instructional Design SLN-based English using Auction strategy is developed based on need analysis and KIBI Indonesian Air Force Students' character. English lesson plan SLNbased using Auction strategy is supplementary and for after-class learning. Learning process can be done synchronously, so students are able to communicate in the learning process in real time. Furthermore, the learning process can be done asynchronously. It means the communication in the process of learning is not done in the real time and students can respond all instructions and answer the questions later. This product can be used for learning every time and everywhere. Lesson used is proper as it is regulated. Alternative for achieving the learning goals for instructor and students may provide individual need to study every time.

The study which is achieved after doing the research on the weaknesses in this SLN-based English using auction strategy lesson plan are displayed as follows:

a. Good internet connection is highly required. b. Applicative learning audio video material used is a must.

c. Need longer time since students might not be able to reach it when offline.

d. Instructor and students might not be able to have intense communication (face to face).

\section{SUGGESTION}

Product which comes to the surface can be used in learning activity, there are few suggestion as follows:

a. Ensure that students have mobile phone with good internet connection.

b. For Pre-Intermediate level above Students.

c. Do the lesson in the real class first then do it in the virtual class.

d. Record the result that has been observed in the observation sheets.

\section{REFERENCES}

Arikunto, S. 2010. Dasar-Dasar Evaluasi Pendidikan (Edisi Revisi). Jakarta: PT. Bumi Aksara.

Burato, E \& Cristani,M. 2009. Learning as Meaning Negotiation: A model Based on English Auction. Berlin Heidelberg : Springer. LNAI 5559,pp.60-69

Dankodikau. 2013. Petunjuk teknis tentanga Penyelenggaraan Operasi Pendidikan Komando Pendidikan TNI Angkatan Udara. Jakarta. Kodikau

Degeng, I.N.S. 2013. Ilmu Pembelajran. Bandung: PT Remaja Rosdakarya

Gale, D \& Kariv, S. 2003. Bayyesian Learning in Social Network. 
Paper. New York : New York

University

Jeff J.S. Huang,Stephen J.H. Yang, Yueh-Min Huang dan Indy Y.T Hsio . 2010. Social Learning Network: Build Mobile Learning Networks Based on Collaborative Services. Journal of Educational Technology \& Society,13(3),78-92

Kasau .2013.Kurikulum Pendidikan Kursus Intensif Bahasa Inggris, No Skep/54/IX/. Jakarta: Mabes TNI AU

Kapp, K.M. 2012. The Gamification of Learning and Instruction: Game Based Methods and Strategies for training and Education. San Francisco: Pfeiffer.

Lee, J,J. \& Hammer, J. 2011.

Gamification in Education:

What, How, Why Bother?.

Academic Exchange Quarterly, (online) 15 (2), (https://www.uwstout.edu/soe/pr ofdev/resources/upload/LeeHammer-AEQ-2011.pdf)

Rugiero, D \& Boehm,J.D.2015.Online Staff Development Module For E-Learning and Pedagogy: Analysis, Design, and Development. International Journal of Design For Learning.Volume 6,issue 1 . Pages 16-25. 